\title{
Innate immunity triggers IL-32 expression by fibroblast-like synoviocytes in rheumatoid arthritis
}

\author{
Ghada Alsaleh 1,2, Laetitia Sparsa ${ }^{11,2}$, Emmanuel Chatelus ${ }^{1,2}$, Mathieu Ehlinger³, Jacques-Eric Gottenberg 1,2, \\ Dominique Wachsmann*1,2 and Jean Sibilia1,2
}

\begin{abstract}
Introduction: Interleukin-32 (IL-32) is a recently described cytokine that is a strong inducer of pro-inflammatory cytokines such as tumor necrosis factor (TNF)- $a, I L-1 \beta, I L-6$, and IL-8. The expression of this cytokine is highly increased in the rheumatoid synovium and correlated with the severity of joint inflammation. Little is known regarding the innate immune-related regulation of IL-32 by fibroblast-like synoviocytes (FLSs). We therefore investigated the effect of innate immune stimulation by ligands of Toll-like receptor (TLR)2, TLR3, and TLR4, and cytokines such as TNF-a and interferon (IFN)- $\gamma$, on IL-32 expression by FLSs.

Methods: FLSs were isolated from patients with rheumatoid arthritis (RA) according to the ACR criteria. Quantitative RT-PCR, confocal analysis, and ELISA were performed to evaluate IL-32 mRNA induction and IL-32 release by FLSs stimulated with TLR2 (BLP), TLR3 (poly l:C), and TLR4 (lipopolysaccharide) ligands, TNF-a and IFN- - .

Results: TLR2, -3 , and -4 ligands as well as IFN- $\gamma$ and TNF- $\alpha$ induced IL-32 $\beta, \gamma$ and $\delta$ mRNA expression by RA FLSs. Mature IL-32 was expressed intracellularly and released by cells stimulated with the various activators. The IL-32a isoform was expressed intracellularly in response to TNF- $a$ and poly $\mathrm{l}: \mathrm{C}$ and not released in culture supernatants. Stimulation of FLS with TNF-a, BLP, lipopolysaccharide, or poly I:C concomitant with IFN- $\gamma$ increased IL-32 expression compared with stimulation with IFN- $\gamma$ alone.

Conclusions: IL-32 synthesis by FLSs is tightly regulated by innate immunity in rheumatoid arthritis. Thus TNF-a, IFN- $\gamma$, double-strand RNA, hyaluronic acid, or other damage-associated molecular patterns (DAMPs), highly secreted in synovial tissues of RA patients, might trigger IL-32 secretion by FLSs. IL-32 might therefore represent a relevant therapeutic target in RA.
\end{abstract}

\section{Introduction}

Rheumatoid arthritis (RA) is a systemic inflammatory disease that affects predominantly multiple peripheral joints. Although the exact mechanisms that contribute to the pathogenesis are still largely unknown, it is well accepted that numerous inflammatory cells such as $\mathrm{T}$ and $B$ cells, fibroblast-like synoviocytes, antigen-presenting cells, and their extensive production of proinflammatory mediators such as TNF- $\alpha$, IL-1, IL-6, IL-15, IL-17, and IL18 , are implicated [1].

IL-32, a recently described cytokine produced mainly by NK cells, T lymphocytes, epithelial cells, and blood

* Correspondence: dominique.wachsmann@pharma.u-strasbg.fr

1 EA3948, Laboratoire Physiopathologie des Arthrites, Université de Strasbourg,

UFR Sciences Pharmaceutiques, 74 route du Rhin, 67401 IIlkirch, France

+ Contributed equally

Full list of author information is available at the end of the article monocytes stimulated by IL- 2 or IFN- $\gamma$, has recently emerged as an important player in innate immune responses $[2,3]$. This proinflammatory cytokine is a strong inducer of other proinflammatory cytokines such as TNF- $\alpha$, IL-1 $\beta$, IL-6, IL-8, and macrophage inflammatory protein-2 (MIP-2) [3-5]. More recently, it was shown that IL-32 increases IFN- $\gamma$ production by PBMCs $[6,7]$. IL-32 might play an important role in inflammatory diseases such as inflammatory bowel diseases and RA [810]. IL-32 is highly expressed in RA synovial tissues but not in OA synovial biopsies. Microarray studies in cultured FLSs obtained from patients with RA have shown that the IL-32 gene is one of the most prominently expressed in RA FLSs [11]. Synovial expression of IL-32 is strongly correlated with that of TNF- $\alpha$ and IL- $1 \beta$ but also with the severity of joint inflammation. 
Current evidence indicates that FLSs, which constitute the synovial lining, are key actors in pannus formation and the subsequent destruction of cartilage and bone in the joint [12]. Activation of FLSs may be linked either to the cytokine environment, to cell-to-cell contacts, or to interactions between pathogen-associated molecular patterns (PAMPs) or damage-associated molecular patterns (DAMPs) and pattern-recognition receptors (PRRs). Bacterial products, such as lipopolysaccharide (LPS) or peptidoglycan, are known to activate FLSs by interacting with PRRs present on these cells $[13,14]$. A large number of PRRs, such as TLR2, TLR4, and TLR3, are expressed by FLSs, and their expression is increased in response to inflammatory stimuli $[15,16]$.

FLSs exert a pro-inflammatory activity, essentially by synthesizing cytokines, chemokines, prostanoids, and nitric oxide (NO) [12]. Secretion by FLSs of some cytokines, like IL-6, IL-8, and B-cell-activating factor is regulated by TNF- $\alpha$, IFN- $\gamma$, and PAMPS $[17,18]$. We therefore investigated the effect of innate immune stimulation by ligands of TLR2, TLR3, TLR4, and cytokines such as TNF- $\alpha$ and IFN- $\gamma$, on IL-32 expression by FLSs.

\section{Materials and methods Cell culture}

Human FLSs were isolated from synovial tissues from four different RA and OA (osteoarthritis) patients at the time of knee-joint arthroscopic synovectomy, as described previously [19]. The diagnosis conformed to the revised criteria of the American College of Rheumatology [20]. Normal FLSs were isolated from synovial tissues obtained with arthroscopic biopsy. Informed consent was provided according to the Declaration of Helsinki and obtained from all patients. Approval by the ethical committee of the Hopitaux Universitaires de Strasbourg was obtained. FLS cultures were made as previously described [21]. Experiments were performed between the third and the ninth passages. Cell number and cell viability were checked by the MTT test, as described elsewhere [22].

\section{Stimulation of cells}

FLSs $\left(10^{6}\right.$ cells) were stimulated with $2 \mathrm{ml}$ of medium alone or medium containing IFN- $\gamma(0.1 \mathrm{ng} / \mathrm{ml})$, TNF- $\alpha$ (10 ng/ml) (R\&D Systems, Lille, France), LPS from Salmonella abortus equi (Sigma, St. Quentin Fallavier, France) $(1 \mu \mathrm{g} / \mathrm{ml})$, BLP (EMC Microcollections GMBH, Tübigen, Germany) $(1 \mu \mathrm{g} / \mathrm{ml})$, and poly I:C (Invivogen, Toulouse, France) $(10 \mu \mathrm{g} / \mathrm{ml})$. After a 4 - or $24-\mathrm{h}$ incubation period, total RNA was extracted by using TRIzol according to the manufacturer's instructions. FLS $(2 \times$ $10^{5}$ cells) were stimulated with $1 \mathrm{ml}$ of complete medium containing the various activators for $24 \mathrm{~h}$. An IL-32 $\alpha$ specific ELISA test was obtained from Biolegend (Ozyme,
Saint Quentin en Yveline, France). IL-32 release was measured with ELISA with the monoclonal antibody KU3256 as a capture antibody and the biotinylated monoclonal antibody KU32-52 as the detection antibody, according to the manufacturer's instructions (Biolegend, Ozyme, Saint Quentin en Yveline, France). The IL-6-specific ELISA test was from R\&D Systems.

\section{Real-time quantitative RT-PCR}

Total RNA isolated from FLSs was reverse transcribed by using the First Strand cDNA Synthesis Kit, according to the manufacturer's instructions (In Vitrogen). Real-time quantitative RT-PCR was performed in a total volume of $20 \mu \mathrm{l}$ by using a SensiMix Plus SYBR (Quantace; Corbett Life Science, Sydney, Australia) and gene-specific primers:

$$
\begin{aligned}
& \text { IL-32: 5'-TGAGGAGCAGCACCCAGAGC-3' } \\
& \text { and 5'-CCGTAGGACTGGAAAGAGGA-3' } \\
& \text { IL-32 } \alpha \text { : 5'-CTGAAGGCCCGAATGCACCA-3' } \\
& \text { and 5'-CCGTAGGACTTGTCACAAAA-3' } \\
& \text { IL-32ß: 5'-CTGAAGGCCCGAATGCACCAG-3' } \\
& \text { and 5'-GCAAAGGTGGTGTCAGTATC-3' } \\
& \text { IL-32 } \gamma: \text { 5'-TGACATGAAGAAGCTGAAGGC-3' } \\
& \text { and 5'-CATGACCTTGTCACAAAAGCTC-3' } \\
& \text { IL-32 } \delta \text { : 5'-TCTCTGATGACATGAAGAAGCT-3' } \\
& \text { and 5'-GCAAAGGTGGTGTCAGTATC-3' } \\
& \text { GAPDH: 5'-GGTGAAGGTCGGAGTCAACGGA-3' } \\
& \text { and 5'-GAGGGATCTCGCTCGCTCCTGGAAGA-3' } \\
& \text { IRF-1: 5'-AAAAGGAGCCAGATCCCAAGA-3' } \\
& \text { and 5'-CATCCGGTACACTCGCACAG-3' } \\
& \text { IRF-3: 5'-AGCAGAGGACCGGAGCAA-3' } \\
& \text { and 5'-AGAGGTGTCTGGCTGGGAAA-3' }
\end{aligned}
$$

IL-32 isoforms were reverse transcribed and amplified. Amplification products were detected as an increased fluorescent signal of SYBRGreen during the amplification cycles. Results were obtained by using SDS Software (Perkin Elmer) and evaluated by using Excel (Microsoft). Melting-curve analysis was performed to assess the specificity of PCR products. Results were normalized to GAPDH and expressed as the fold change compared with samples from cells incubated in medium.

\section{Immunostaining and confocal microscopy}

FLSs $\left(5 \times 10^{4}\right.$ cells/well; IbiTreat slides) were stimulated with medium containing the various activators. After a 16-h incubation-period, cells were fixed with paraformaldehyde, $4 \%$, at $4^{\circ} \mathrm{C}$, washed with PBS, and permeabilized with $0.2 \%$ Triton X100 in PBS, pH 7.4, for 10 min. FLSs were incubated with goat anti-IL-32 antibodies (Santa Cruz Biotechnology, Santa Cruz, CA, USA) overnight at $4^{\circ} \mathrm{C}$ and then with FITC rabbit anti-goat antibodies for 1 $\mathrm{h}$ at $25^{\circ} \mathrm{C}$. Fluorescence was analyzed with confocal microscopy. 


\section{Detection of cellular IL-32a}

FLSs $\left(2 \times 10^{4}\right.$ cells) were seeded into 96 -well plates and then incubated for $16 \mathrm{~h}$ and $24 \mathrm{~h}$ in $200 \mu \mathrm{l}$ of complete medium containing the different activators. Cells were then fixed with $4 \%$ paraformaldehyde in PBS, pH 7.4, for $20 \mathrm{~min}$. Free aldehyde groups were quenched with $\mathrm{NH}_{4} \mathrm{Cl}, 50 \mathrm{mM}$, in PBS, $\mathrm{pH}$ 7.4, for $20 \mathrm{~min}$. Nonspecific binding was blocked by incubation in PBS containing $0.2 \%$ bovine serum albumin and $0.05 \%$ saponin for $30 \mathrm{~min}$ at $37^{\circ} \mathrm{C}$. The cells were then incubated with biotinylated anti-IL-32 $\alpha$ antibodies (Biolegend; Ozyme, Saint Quentin en Yveline, France) for $2 \mathrm{~h}$. Absorbance was measured at $450 \mathrm{~nm}$.

\section{Transfections}

The siRNA duplexes used in our study were designed to target sequences for human IRF-1 [GenBank: NM 002198] gene. Four selected siRNA oligonucleotides consisting of sequences of 21 nucleotides were supplied by Dharmacon (Perbio Science, France). Transient transfection of FLSs with siRNA (100 $\mathrm{n} M)$ was performed by using the Human Dermal Fibroblast Nucleofactor kit from Amaxa, as previously described [23]. FLSs were then plated in 24 -well plates $\left(2 \times 10^{5}\right.$ cells per well). All assays were performed $48 \mathrm{~h}$ after transfection. The control was carried out with the Dharmacon siControl nontargeting siRNA consisting of a four-oligonucleotide pool. Transfection efficiency was evaluated with the PmaxGFP control vector.

\section{Statistical analysis}

Values are expressed as mean \pm SEM. The significance of the results was analyzed with Wilcoxon's test. The $P$ values $<0.05$ were considered significant.

\section{Results}

\section{Effect of IFN- $\gamma$ and TNF- $\alpha$ on IL-32 synthesis and release by activated RA FLSs}

Stimulation of RA FLSs with IFN- $\gamma$ induced a dosedependent production of IL-32 transcripts, which were detectable within $4 \mathrm{~h}$ (Figure 1a). IL-32mRNA expression was also compared in normal, OA, and RA FLSs activated with $0.1 \mathrm{ng} / \mathrm{ml}$ of IFN- $\gamma$. As shown in Figure 1a, amounts of IL-32 transcripts were higher in stimulated RA FLSs compared with normal and OA FLSs.

We next investigated the expression of the different isotypes in RA FLSs. Treatment with IFN- $\gamma$ at a concentration of $0.1 \mathrm{ng} / \mathrm{ml}$ resulted in an increasing amount of IL$32 \beta, \gamma$, and $\delta$ transcripts, which were detectable within 4 $\mathrm{h}$ (Figure 1b), with a mean increase of seven-, three-, and fivefold after stimulation for $24 \mathrm{~h}$, respectively (Figure 1c). IL-32 $\alpha$ mRNA was not expressed at 4 and $24 \mathrm{~h}$ (Figure $1 \mathrm{~b}, \mathrm{c}$ ). To determine whether increased IL-32 mRNA synthesis led to IL-32 protein expression, immunostain- ing was performed with a polyclonal anti-human IL-32 antibody, which detected all isoforms $(\alpha, \beta, \gamma, \delta)$. By using confocal microscopy, no basal expression of IL-32 was observed in unstimulated FLS (Figure 1d/a). IL-32 was strongly expressed after a 24- $\mathrm{h}$ incubation with IFN- $\gamma$ (Figure 1d/c). By using an ELISA test that detected IL-32, we observed that IFN- $\gamma$ induced IL-32 release by FLSs at $24(55 \mathrm{pg} / \mathrm{ml} \pm 18 \mathrm{pg} / \mathrm{ml})$ and $48 \mathrm{~h}(125 \mathrm{pg} / \mathrm{ml} \pm 30 \mathrm{pg} /$ $\mathrm{ml}$ ), compared with nonactivated cells (Figure 1e). The $\alpha$ isoform of IL-32 (IL-32 $\alpha$ ) protein was neither detected intracellularly in IFN- $\gamma$-activated FLSs (Figure 1f) nor released (data not shown).

Stimulation of RA FLSs with TNF- $\alpha$ induced a dosedependent production of IL-32 mRNA, which was detectable within $4 \mathrm{~h}$ (Figure 2a). By using normal, OA, and RA FLSs activated with $5 \mathrm{ng} / \mathrm{ml}$ of TNF-a, we observed that amounts of IL-32 transcripts were higher in stimulated RA FLSs compared with normal and OA FLSs (Figure 2a).

We then assessed the expression of the different isotypes. After stimulation with TNF- $\alpha$, IL-32 $\alpha, \beta, \gamma$, and $\delta$ mRNA were detectable within $4 \mathrm{~h}$, with a mean increase of four-, nine-, five- and eightfold after stimulation for 24 $h$, respectively (Figure $2 b, c)$. Protein expression and release by TNF- $\alpha$-activated FLSs was demonstrated by immunostaining (Figure 2d/c) and by ELISA (Figure 2e). Mature IL-32 $\alpha$ was detected intracellularly (Figure $2 f$ ) but not released (data not shown).

\section{Effect of LPS, BLP, and poly I:C on IL-32 synthesis and release by RA FLSs}

IL-32 mRNA expression was also compared in normal, OA, and RA FLSs activated with TLR ligands (LPS, BLP, and poly I:C). As shown in Figure 3a, amounts of IL-32 transcripts were higher in stimulated FLSs isolated from RA patients compared with OA and normal FLSs.

IL-32 $\beta, \gamma$, and $\delta$ mRNA expression was induced in RA FLSs in response to either BLP or poly I:C after $4 \mathrm{~h}$ (Figure $3 \mathrm{~b}$ ), with a lower induction after a 24-h stimulation (Figure 3c). LPS induced only IL-32 $\beta$ and $\delta$ isoforms (Figure $3 b$ ). An increase (fivefold) of IL-32 $\alpha$ mRNA was detected only in poly I:C-activated FLS (Figure 3b, c). Immunostaining and ELISA demonstrated the presence and release of mature IL-32 protein in FLSs stimulated by LPS, BLP, and poly I:C (Figure $3 \mathrm{~d} / \mathrm{c}, / \mathrm{d}$,/e and $3 \mathrm{e}$ ). IL-32 $\alpha$ was also expressed intracellularly in response to poly I:C (Figure 3f) but not released (data not shown).

The inflammatory environment of the synovial cavity is complex in RA, because most of cytokines are present in the synovial cavity and can interact with each other. We therefore investigated whether a combination of TNF- $\alpha$ $(10 \mathrm{ng} / \mathrm{ml})$ and IFN- $\gamma(0.1 \mathrm{ng} / \mathrm{ml})$ could modulate levels of IL-32 mRNA expression by FLSs, because FLS are exposed to both cytokines in the synovium during RA. 


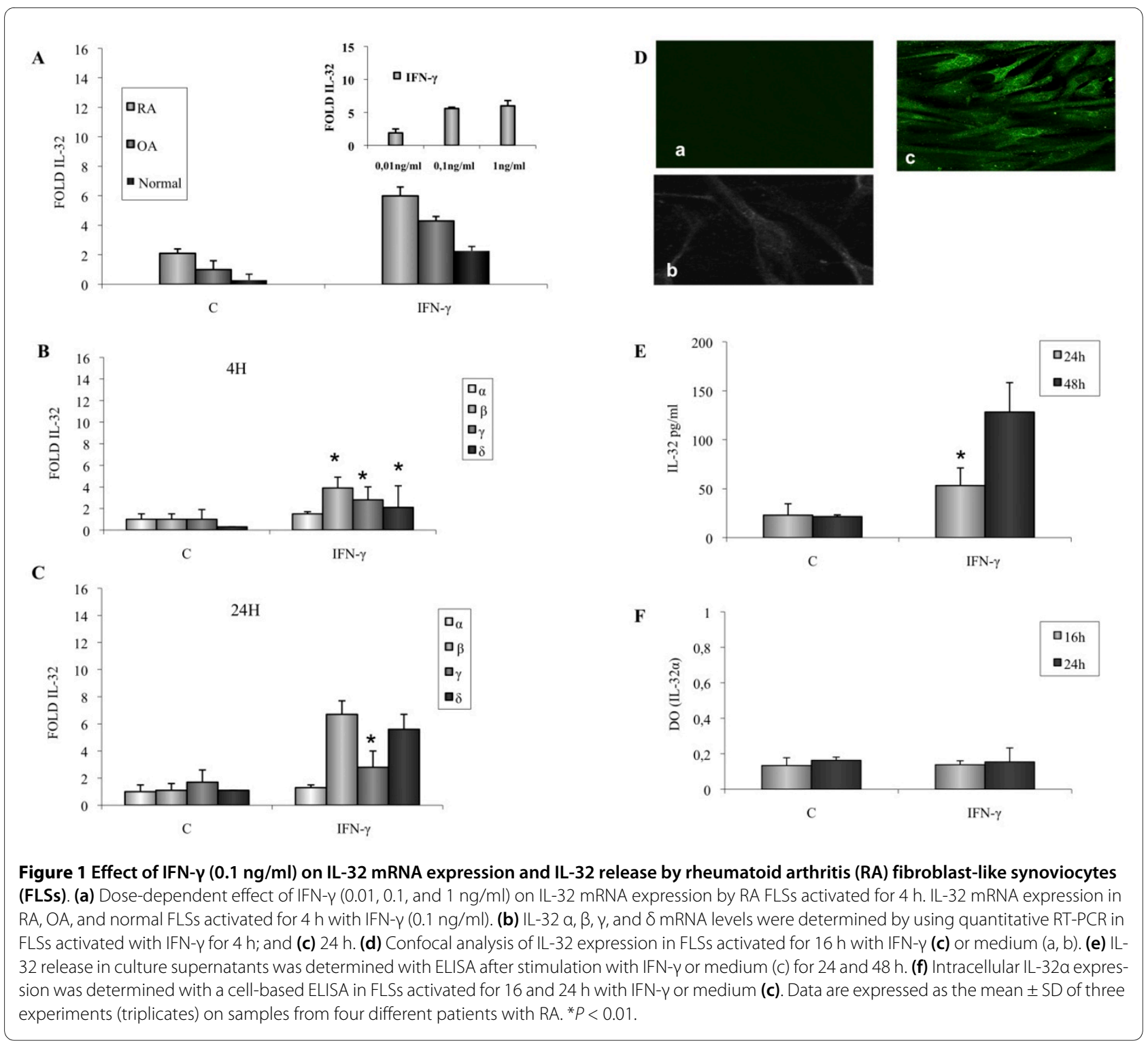

Concomitant stimulation of FLS with IFN- $\gamma$ and TNF- $\alpha$ resulted in a strong induction of IL-32 mRNA expression as compared with stimulation with only one of these cytokines. This synergistic effect was observed in IL-32 mRNA $4 \mathrm{~h}$ and $24 \mathrm{~h}$ after activation with TNF- $\alpha$ and IFN$\gamma$ (Figure 4a) but was not observed at the protein level by using ELISA (Figure 4b). However, a concordant effect on mRNA and protein stimulation with both cytokines was demonstrated for the $\alpha$ isoform of IL-32 (Figure 4c, d).

We also studied the effect of a concomitant stimulation of IFN- $\gamma(0.1 \mathrm{ng} / \mathrm{ml})$ and either BLP, LPS, or poly I:C. Stimulation of FLS with IFN- $\gamma(0.1 \mathrm{ng} / \mathrm{ml})$ and either of these PAMPs strongly induced the transcript levels of IL32 mRNA as compared with FLSs activated with the same amount of IFN- $\gamma$ alone (Figure 5a). This effect was observed after $4 \mathrm{~h}$ of stimulation but not after $24 \mathrm{~h}$. A synergistic effect on IL-32 release was observed after activation with IFN- $\gamma$ and either LPS, BLP, or poly I:C (Figure $5 b)$. Moreover, LPS, BLP, and poly I:C also exert a synergistic effect on IL-32 $\alpha$ mRNA synthesis and IL-32 $\alpha$ intracellular expression, when combined with IFN- $\gamma$ (Figure $5 \mathrm{c}, \mathrm{d})$.

\section{Role of IRF-1 in the synergistic induction of IL-32}

We subsequently analyzed the mechanisms responsible for the synergistic effect of PAMPs or TNF- $\alpha$ on IFN- $\gamma$ related IL-32 induction. Previous studies showed that nuclear concentrations of IFN regulatory factor-1 (IRF-1) were found to increase after stimulation with IFN- $\gamma$ and TNF- $\alpha$ compared with stimulation with individual cytokines [24,25]. We therefore evaluated IRF-1 mRNA expression in RA FLSs, stimulated with either TNF- $\alpha$ or IFN- $\gamma$ alone or in combination. Stimulation with IFN- $\gamma$ induced 


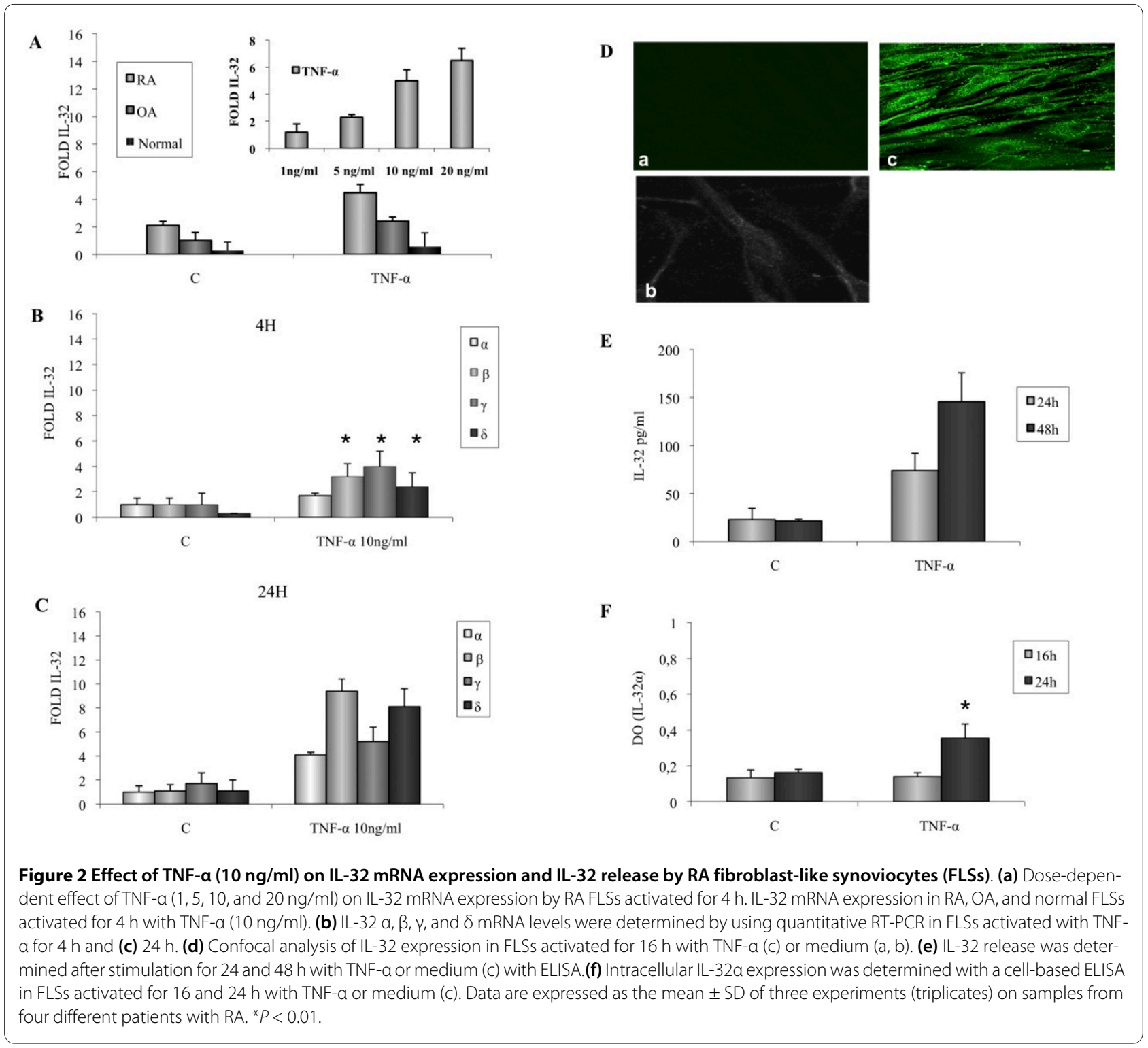

IRF-1 mRNA expression in activated RA FLSs, and concomitant stimulation of FLSs with IFN- $\gamma$ and TNF- $\alpha$ resulted in a stronger increase of IRF-1 mRNA expression (Figure 6a). These results indicate that a simultaneous stimulation with TNF- $\alpha$ has a synergistic effect on IFN- $\gamma$ induced IRF-1 transcription in FLSs.

To determine whether IRF-1 is necessary for IL-32 mRNA synthesis by stimulated FLSs, cells were transfected with siRNA targeting IRF-1 or control siRNA for $48 \mathrm{~h}$ and then stimulated with TNF- $\alpha$ and IFN- $\gamma$ alone or in combination. Transfection with siRNAs did not affect cell viability, assessed by the MTT test. We first confirmed that transfection of siRNA targeting IRF-1 impaired endogenous IRF-1mRNA expression, as compared with IRF-1 expression in cells transfected with a nontargeting, control siRNA (Figure 6b). Inhibition of
IRF-1 significantly reduced IL-32 mRNA expression after TNF- $\alpha$, IFN- $\gamma$, and TNF- $\alpha+$ IFN- $\gamma$ stimulation of FLSs (Figure 6c). This role of IRF-1 in the synergy between TNF- $\alpha$ and IFN- $\gamma$ was specific to IL-32, because the release of IL-6, another proinflammatory cytokine, was not modified after inhibition of IRF-1 (Figure 6d). Stimulation with either LPS, BLP or poly I:C did not induce IRF-1 mRNA expression but IRF-3 mRNA (Figure 6e), and no synergic effect either on IRF-1 or IRF-3 mRNA expression was observed when FLSs were concomitantly stimulated with IFN- $\gamma$ and LPS, BLP, or poly I:C (Figure 6e). Likewise, by using IRF-1 siRNA, the synergy between LPS and IFN- $\gamma$ was not modified (Figure 6f), converse to that observed after stimulation with IFN- $\gamma$ and TNF- $\alpha$. Thus, these results indicate that IRF-1 is involved in the synergistic effect of TNF- $\alpha$ and IFN- $\gamma$ on IL-32 mRNA 


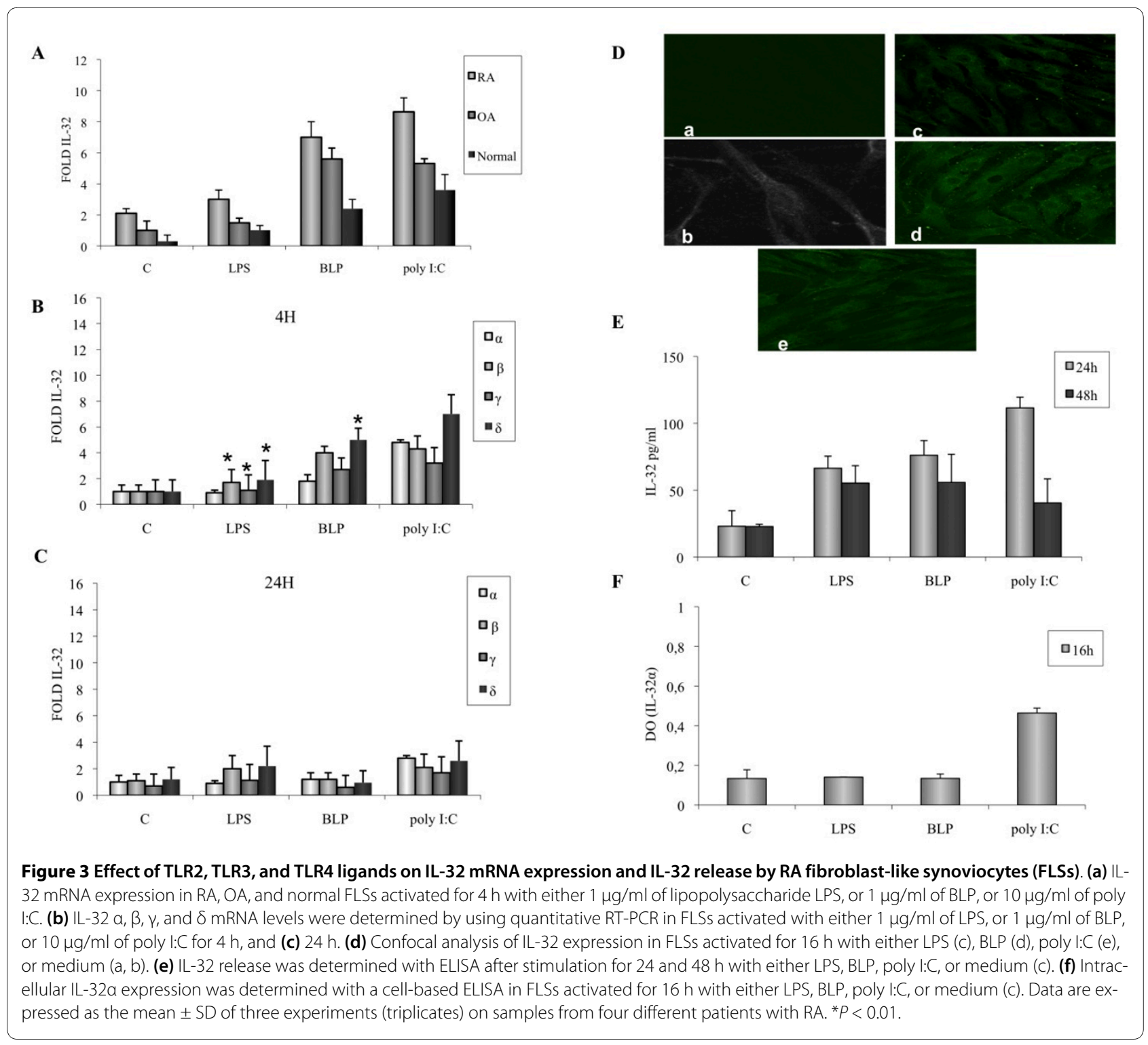

expression by activated FLSs, but IRF-1 and IRF-3 are not implicated in the synergy for the induction of IL-32 observed between IFN- $\gamma$ and the PAMPs studied.

\section{Discussion}

The synovial expression of IL-32, a potent proinflammatory cytokine, is increased in RA and correlated with disease activity [10]. A recent study demonstrated that resident cells of joints, FLSs, which secrete proinflammatory cytokines such as IL- 6 and IL- 8 but not TNF- $\alpha$ or IL$1 \beta$, secrete high levels of IL-32 [26,27]. The expression of cytokines by FLSs is regulated, at least partly, by innate immunity. However, little is known regarding the innateimmune-related regulation of IL-32 by FLSs. We demonstrated that proinflammatory cytokines involved in the pathogenesis of RA, as well as stimulation of various TLR receptors, result in the expression of IL-32 by FLSs, key target and resident cells of RA. Moreover, a synergistic interaction between IFN- $\gamma$ and PAMPs for IL-32 induction was observed. We demonstrated that synergy between TNF- $\alpha$ and IFN- $\gamma$ was related to the induction of IRF-1.

We first confirmed studies from Mun et al. [26] and Shoda et al. [27], demonstrating that activation of FLSs with TNF- $\alpha$ caused IL-32 synthesis and release. The ability of IFN- $\gamma$ to induce IL-32 production in epithelial cells and monocytes was previously reported by Kim et al. [3]. IFN- $\gamma$ is produced in RA by either by $\mathrm{CD}^{+} \mathrm{T}$ cells, or by subsets of $\mathrm{CD}^{+} \mathrm{CD} 40 \mathrm{~L} \mathrm{~T}$ cells or $\mathrm{CD} 4{ }^{+} \mathrm{T}$ cells, which express KIR2DS2 and NKG2D receptors. Immunohistochemical studies have shown the reinforced expression of Stat proteins in rheumatoid synovial tissues, which 

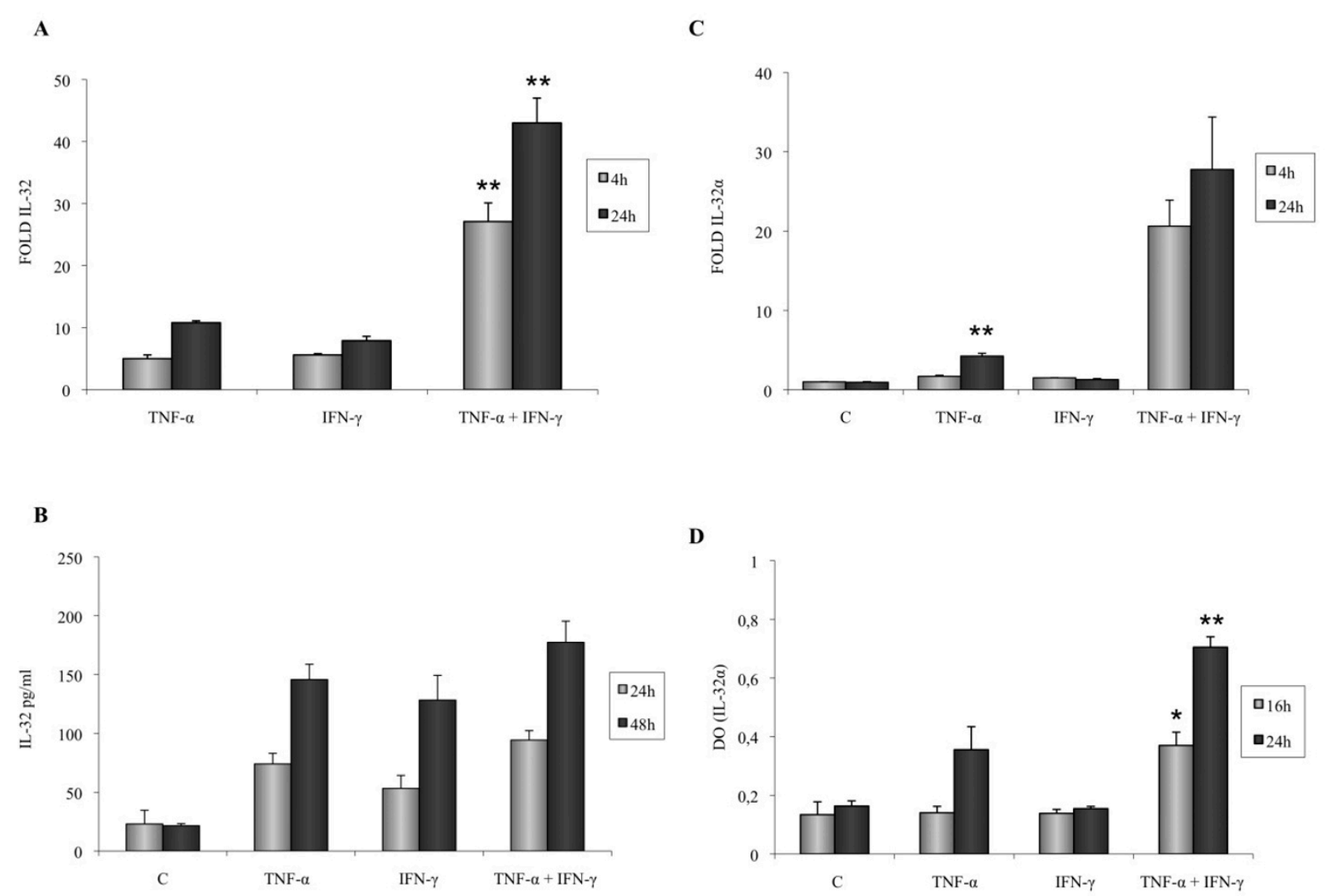

Figure 4 Effect of co-stimulation of TNF- $\alpha(10 \mathrm{ng} / \mathrm{ml})$ and IFN- $\gamma(0.1 \mathrm{ng} / \mathrm{ml})$ on IL-32 mRNA expression and IL-32 release by RA fibroblastlike synoviocytes (FLSs). (a) FLSs were incubated simultaneously with IFN- $\gamma$ and TNF- $a$, and IL-32 mRNA levels were determined after activation for $4 \mathrm{~h}$ and $24 \mathrm{~h}$ by using quantitative RT-PCR. (b) IL-32 release was determined with ELISA in culture supernatants. (c) IL-32a mRNA levels were determined by using quantitative RT-PCR in FLSs activated with either IFN- $\gamma$ and TNF-a or medium (c). (d) Intracellular IL-32a expression was determined in IFN- $\gamma+$ TNF- $a$ - or medium-activated (c) FLSs. Data are expressed as the mean \pm SD of three experiments (triplicates) on samples from four different patients with RA. ${ }^{*} P<0.01 ; * * 0<0.001$.

suggests the importance of the IFN- $\gamma /$ JAK/Stat pathway $[28,29]$. Moreover, under most conditions in RA, IFN- $\gamma$ release correlates with TNF- $\alpha$ production [30]. We therefore assessed the role of IFN- $\gamma$ in IL-32 synthesis and secretion by FLSs. Exposure to IFN- $\gamma$ increased IL-32 mRNA transcription and protein release, as demonstrated for TNF- $\alpha$. In RA FLSs, IFN- $\gamma$ is unlikely to function as a direct inducer of proinflammatory cytokines synthesis, such as that of TNF- $\alpha$, IL-6, and IL-8 [17]. Thus, these data suggest that IFN- $\gamma$, by means of IL-32 release, might play an important role in the amplification of inflammatory reactions in RA.

An important issue relevant to this study is represented by the induction of IL-32 mRNA transcription in response to LPS, BLP, and poly I:C. This effect was particularly significant in response to BLP and poly I:C at $4 \mathrm{~h}$, with a decrease at $24 \mathrm{~h}$ corresponding to a kinetic different from the one obtained with IFN- $\gamma$ and TNF- $\alpha$. However, this is frequently observed with certain cytokines such as TNF- $\alpha$. These findings are not concordant with results from Netea's group [7] on activated PBMCs, showing that TLR2 and TLR3 ligands did not induce an increase in IL-32 release. In keeping with their results, we also observed that LPS was a moderate inducer of IL-32 expression in RA FLSs.

IL-32 is transcribed as six alternative splice variants. Splice variants are quite unusual for cytokines, but they exist in other cytokines such as IL-15 and IL-1F7. The four spliced variants are expressed in TNF- $\alpha$-stimulated RA FLSs, but their respective roles in RA pathogenesis remain to be determined [31]. In this study, we observed that $\beta, \gamma$, and $\delta$ isoforms were transcribed in FLSs activated with either TNF- $\alpha$, IFN- $\gamma$, BLP, or poly I:C. The $\beta$ and $\delta$ isoforms were moderately induced by LPS.

Interestingly, we demonstrated that IL- $32 \alpha$ mRNA is upregulated in response to TNF- $\alpha$ and poly I:C and that this variant is only cell associated in FLSs and never released. This is in agreement with a study in PBMCs showing that IL-32 $\alpha$ expression is upregulated in response to Mycobacterium tuberculosis and remained 

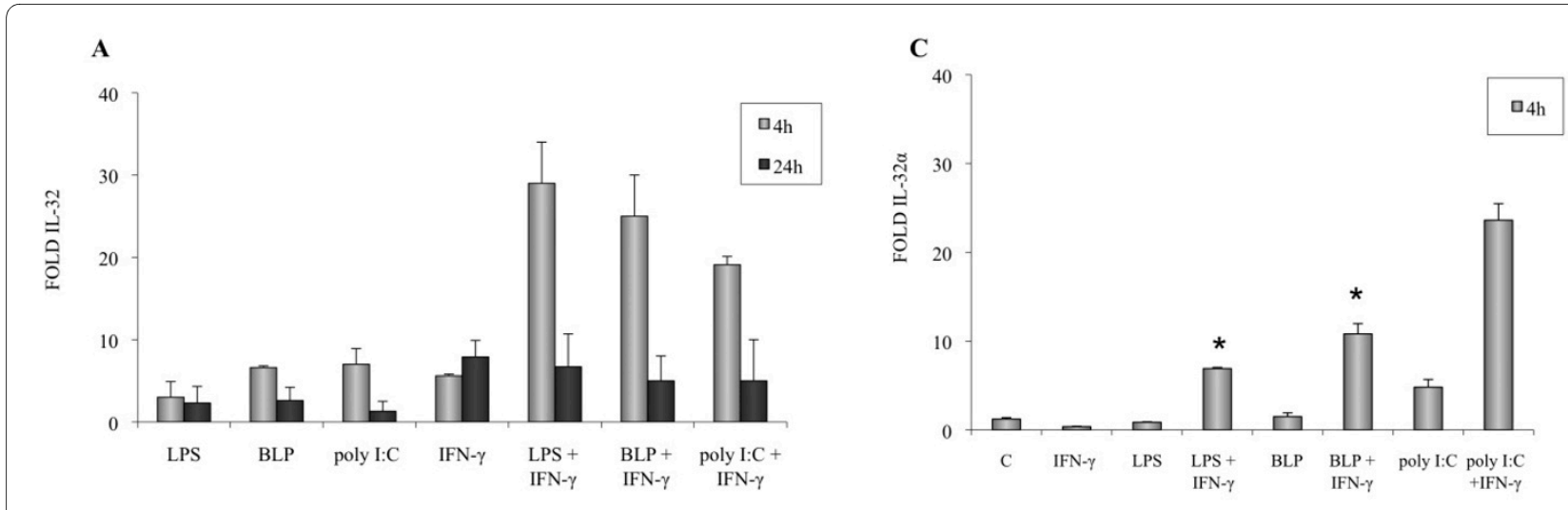

B

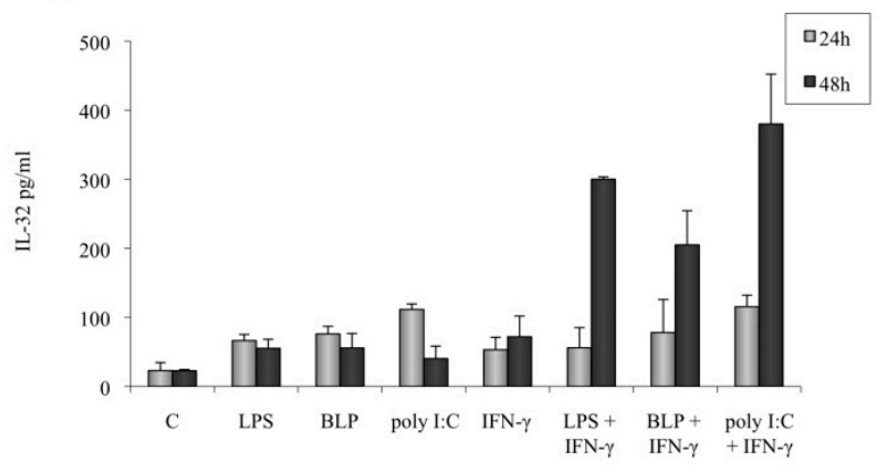

D

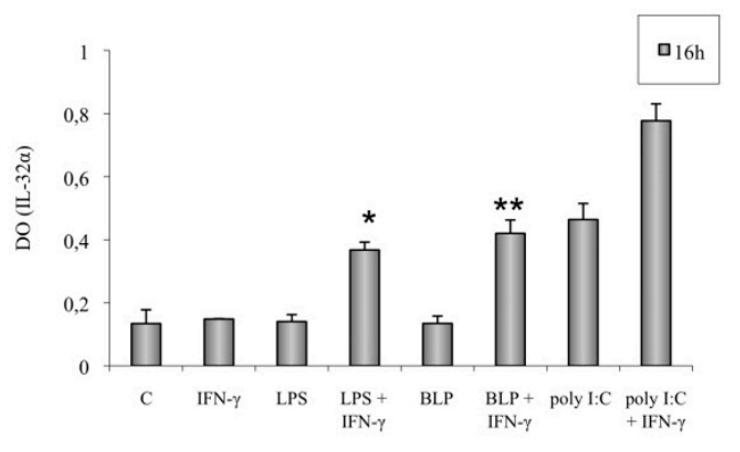

Figure 5 Effect of co-stimulation of IFN- $\gamma(0.1 \mathrm{ng} / \mathrm{ml})$ with either lipopolysaccharide (LPS; $1 \mu \mathrm{g} / \mathrm{ml})$, BLP $(1 \mu \mathrm{g} / \mathrm{ml})$, or poly I:C (10 $\mu \mathrm{g} / \mathrm{ml})$ on IL-32 mRNA expression and IL-32 release by RA fibroblast-like synoviocytes (FLSs). (a) FLSs were incubated simultaneously with IFN- $\gamma$ and either LPS, BLP, or poly I:C. IL-32 mRNA levels were determined after activation by using quantitative RT-PCR, and IL-32 release was determined with ELISA (b). (c) IL-32a mRNA levels were determined with quantitative RT-PCR. (d) Intracellular IL-32a expression was evaluated in FLSs with a cell-based ELISA. Data are expressed as the mean \pm SD of three experiments (triplicates) on samples from four different patients with RA. ${ }^{*} P<0.01$; ${ }^{* *} P<0.001$.

cell associated [7]. This effect might depend on cell-type, because IL-32 $\alpha$ can be released by some epithelial cells lines in response to IFN- $\gamma$, TNF- $\alpha$ and IL- $1 \beta$ [9].

IFN- $\gamma$ and TNF- $\alpha$ are cytokines characterized by complex reciprocal effects. They synergize to increase collagen synthesis by dermal fibroblasts or glycosaminoglycans synthesis by lung fibroblasts, and they are tightly involved in the inflammatory response during septic shock $[32,33]$. An important result is that IRF-1 is required for the synthesis of IL- 32 by TNF- $\alpha$. Its role in IFN- $\gamma$ signaling is well known, but not in TNF- $\alpha$ signaling. We also showed that this effect is specific, as IRF-1 does not play any role in IL-6 synthesis. Of note in the present study, TNF- $\alpha$ exerts a synergistic effect on IFN- $\gamma$ - induced IL-32 mRNA, which is related to IRF-1 upregulation. The expression of IL-32 mRNA was considerably reduced (70\%) after inhibition of IRF-1 in FLSs activated with a combination of TNF- $\alpha$ and INF- $\gamma$.

Unexpectedly, release of IL-32 protein, was not increased after TNF- $\alpha$ and IFN- $\gamma$ stimulation, but the intracellular expression of the IL-32 $\alpha$ was upregulated. Similar results were obtained in epithelial cells, in which a combination of TNF- $\alpha$ and INF- $\gamma$ increased IL-32 $\alpha$ expression [9]. Knowledge of the role of intracellular IL32 is still limited, but IL-32 $\alpha$ may play a role as a cytoplasmic protein. Recently it was demonstrated that IL-32 $\alpha$ acts synergistically with NOD-specific peptidoglycans for the release of inflammatory cytokines [5].

Concomitant stimulation with IFN- $\gamma$ and other TLR ligands also increased IL-32 mRNA expression and protein release, but the mechanism involved in these synergies remains to be identified. We demonstrated that they are not related to IRF-1, converse to the synergy between IFN- $\gamma$ and TNF- $\alpha$. Thus, these concomitant stimulations did not upregulate IRF-1, and IRF-1 silencing did not inhibit the synergy between IFN- $\gamma$ and PAMPs for IL-32 induction. A hallmark of tissue injury is the turnover of extracellular matrix components, which can subsequently act as DAMPs. Increased accumulation of fragmented hyaluronan was noticed in several autoimmune diseases. 


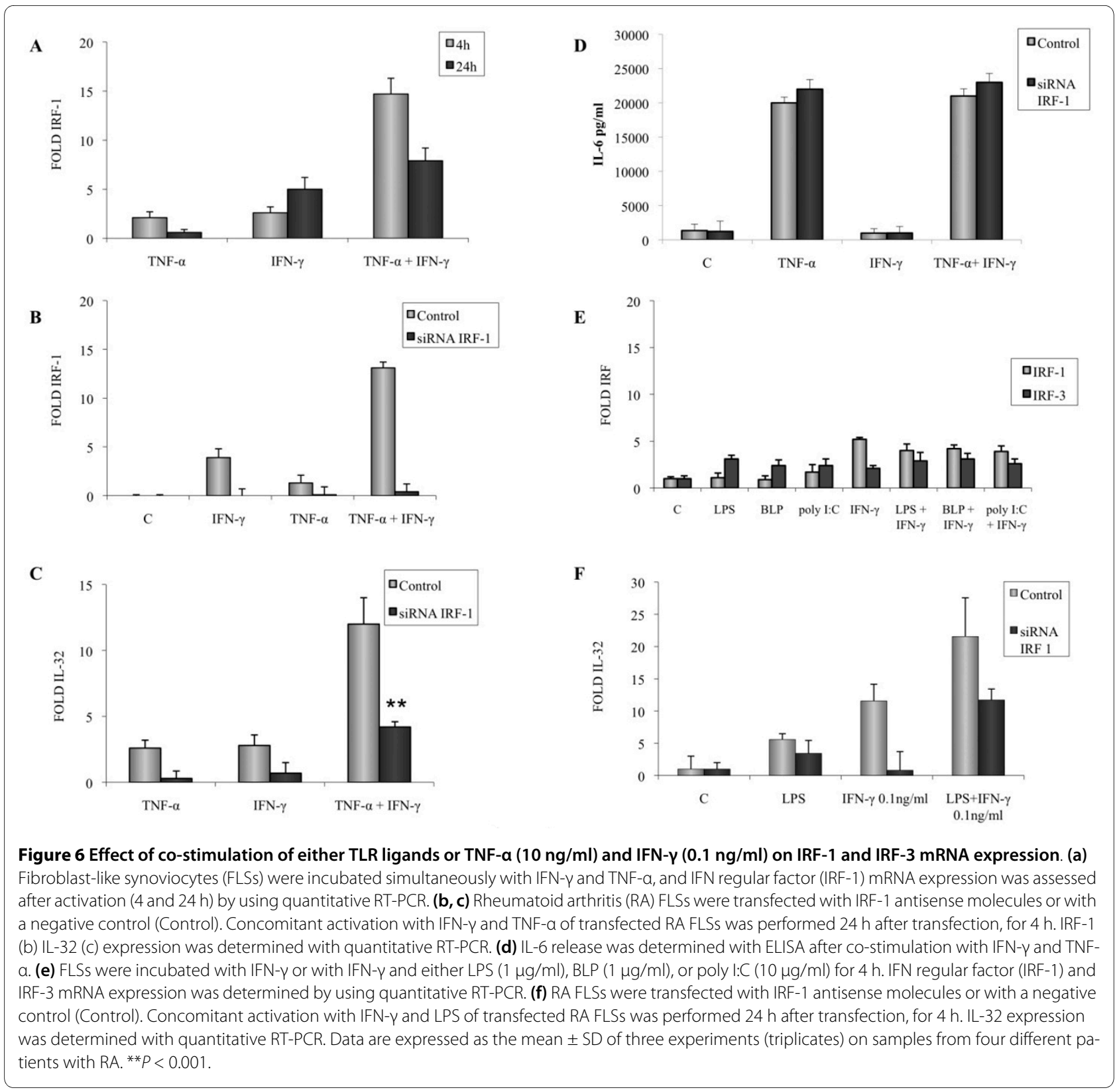

Hyaluronan fragments signal through TLR2 and TLR4 in macrophages, and tenascin-C activates TLR4 in macrophages and FLSs $[34,35]$. Moreover, RNA release from necrotic cells acts as and endogenous TLR3 ligand for the stimulation of proinflammatory cytokines release [36]. Therefore, our data raise the possibility that triggers, including bacterial components, of endogenous ligands may promote IL-32 synthesis and release by activating TLR pathways.

\section{Conclusions}

IL-32 is known to activate the p38MAPK and the NF-kB signal-transduction pathways and to induce the expression of other proinflammatory cytokines, such as TNF- $\alpha$,
IL-1 $\beta$, and IL-18, partly by amplifying the signals induced by NOD2 [5,7]. Because these cytokines are never released by activated FLSs, the present data suggest that FLSs may play an important role in the amplification of inflammatory reactions in RA, by expressing IL-32, which in turn induces the expression of TNF- $\alpha$, IL-1, or IL-18 by macrophages or dendritic cells, bridging innate and adaptive immunity. IL-32 might therefore represent a relevant therapeutic target in $\mathrm{RA}$.

\section{Abbreviations}

DAMPs: damage-associated molecular patterns; FLS: fibroblast-like synoviocyte; IRF-1: IFN regular factor; LPS: lipopolysaccharide; PAMPs: pathogen-associated molecular patterns; PBMCs: peripheral blood mononuclear cells; PRRs: pattern-recognition receptors; RA: rheumatoid arthritis. 


\section{Competing interests}

The authors declare that they have no competing interests.

\section{Authors' contributions}

GA and LS designed and performed all experiments and drafted the manuscript. EC and ME assisted in designing the study. JS conceived the study. JEG edited the manuscript. DW conceived the study and drafted and edited the manuscript. All authors read and approved the final manuscript.

\section{Acknowledgements}

These experiments were supported by grants from Bristol Myers Squibb, Roche, Pfizer, Courtin Fundation and CAMPLP.

\section{Author Details}

1EA3948, Laboratoire Physiopathologie des Arthrites, Université de Strasbourg, UFR Sciences Pharmaceutiques, 74 route du Rhin, 67401 IIlkirch, France, 2Département de Rhumatologie, Hôpitaux Universitaires de Strasbourg, avenue Molière, Strasbourg Hautepierre 67200, France and 'Département d'Orthopédie, Hôpitaux Universitaires de Strasbourg, Strasbourg Hautepierre 67200 , France

Received: 26 October 2009 Revised: 30 April 2010

Accepted: 8 July 2010 Published: 8 July 2010

\section{References}

1. Firestein GS: Evolving concept of rheumatoid arthritis. Nature 2003, 423:356-361.

2. Dahl CA, Schall RP, He H, Cairns JS: Identification of a novel gene expressed in activated natural killer cells and T cells. J Immunol 1992, 148:597-603.

3. Kim SH, Han SY, Azam T, Yoon DY, Dinarello CA: Interleukin-32: a cytokine and inducer of TNF-a. Immunity 2005, 22:131-142.

4. Netea MG, Lewis EC, Azam T, Joosten LA, Jaekal J, Bae SY, Dinarello CA, Kim SH: Interleukin-32 induces the differentiation of monocytes into macrophage-like cells. Proc Natl Acad Sci USA 2008, 105:3515-3520.

5. Netea MG, Azam T, Ferwerda G, Girardin SE, Walsh M, Park JS, Abraham E, Kim JM, Yoon DY, Dinarello CA, Kim S: IL-32 synergizes with nucleotide oligomerization domain 1(NOD1) and NOD2 ligands for IL-1 $\beta$ and IL-6 production through a caspase 1-dependent mechanism. Proc Natl Acad Sci U S A 2005, 102:16309-16314.

6. Nold MF, Nold-Petry CA, Pott GB, Zepp JA, Saavedra MT, Kim SH, Dinarello CA: Endogenous IL-32 controls cytokine and HIV-1 production. J Immunol 2008, 181:557-565.

7. Netea MG, Azam T, Lewis EC, Joosten LA, Wang M, Langenberg D, Meng X, Chan ED, Yoon DY, Ottenhoff T, Kim SH, Dinarello CA: Mycobacterium tuberculosis induces interleukin-32 production through a caspase- 1/ IL-18/interferon- $\gamma$-dependent mechanism. PLoS Med 2006, 3:e277.

8. Fantini MC, Monteleone G, MacDonald TT: New players in the cytokine orchestra of inflammatory bowel disease. Inflamm Bowel Dis 2007. 13:1419-1423.

9. Shioya M, Nishida A, Yagi Y, Ogawa A, Tsujikawa T, Kim-Mitsuyama S, Takayanagi A, Shimizu N, Fujiyama Y, Andoh A: Epithelial overexpression of interleukin-32a in inflammatory bowel disease. Clin Exp Immunol 2007, 149:480-486.

10. Joosten LA, Netea MG, Kim SH, Yoon DY, Oppers-Walgreen B, Radstake TR, Barrera P, van de Loo FA, Dinarello CA, van den Berg WB: IL-32, a proinflammatory cytokine in rheumatoid arthritis. Proc Natl Acad Sc USA 2006, 103:3298-3303.

11. Cagnard N, Letourneur F, Essabbani A, Devauchelle V, Mistou S, Rapinat A, Decraene C, Fournier C, Chiocchia G: Interleukin-32, CCL2, PF4F1 and GD10 are the only cytokine/chémokines genes differentially expressed by in vitro cultured rheumatoid and osteoarthritis fibroblast-like synoviocytes. Eur Cytokine Netw 2005, 16:289-292.

12. Muller-Ladner U, Ospelt C, Gay S, Distler O, Pap T: Cells of the synovium in rheumatoid arthritis: synovial fibroblasts. Arthritis Res Ther 2007, 9:223-230.

13. Pierer M, Rethage J, Seibl R, Lauener R, Brentano F, Wagner U, Hantzschel H, Michel BA, Gay RE, Gay S, Kyburz D: Chemokine secretion of rheumatoid arthritis synovial fibroblasts stimulated by Toll-like receptor 2 ligands. J Immunol 2004, 172:1256-1265.
14. Jung YO, Cho ML, Kang CM, Jhun JY, Park JS, Oh HJ, Min JK, Park SH, Kim $\mathrm{HY}$ : Toll-like receptor 2 and 4 combination engagement upregulate IL15 synergistically in human rheumatoid synovial fibroblasts. Immunol Lett 2007, 109:21-27.

15. Kyburz D, Rethage J, Seibl R, Lauener R, Gay RE, Carson DA, Gay S: Bacterial peptidoglycans but not $\mathrm{CpG}$ oligodeoxynucleotides activate synovial fibroblasts by Toll-like receptor signalling. Arthritis Rheum 2003, 48:642-650.

16. Ospelt C, Brentano F, Rengel Y, Stanczyk J, Kolling C, Tak PP, Gay RE, Gay S, Kyburz D: Overexpression of Toll-like receptors 3 and 4 in synovial tissue from patients with early rheumatoid arthritis: Toll-like receptor expression in early and longstanding arthritis. Arthritis Rheum 2008, 58:3684-3692.

17. Alsaleh G, Messer L, Semaan N, Boulanger N, Gottenberg JE, Sibilia J, Wachsmann D: BAFF synthesis by rheumatoid synoviocytes is positively controlled by a $5 \beta 1$ integrin stimulation and is negatively regulated by tumor necrosis factor- $\alpha$ and Toll-like receptor ligands. Arthritis Rheum 2007, 56:3202-3214.

18. Ohata J, Zvaifler NJ, Nishio M, Boyle DL, Kalled SL, Carson DA, Kipps TJ: Fibroblast-like synoviocytes of mesenchymal origin express functional B cell-activating factor of the TNF family in response to proinflammatory cytokines. J Immuno/ 2005, 174:864-870

19. Dechanet J, Taupin JL, Chomarat P, Rissoan MC, Moreau JF, Banchereau J, Miossec P: Interleukin-4 but not interleukin-10 inhibits the production of leukemia inhibitory factor by rheumatoid synovium and synoviocytes. Eur J Immunol 1994, 24:3222-3228.

20. Arnett FC, Edworthy SM, Bloch DA, McShane DJ, Fries JF, Cooper NS, Healey LA, Kaplan SR, Liang MH, Luthra HS, et al:: The American Rheumatism Association 1987 revised criteria for the classification of rheumatoid arthritis. Arthritis Rheum 1988, 31:315-324.

21. Neff L, Zeisel M, Sibilia J, Scholler-Guinar M, Klein JP, Wachsmann D: NF-KB and the MAPkinase/AP-1 pathways are both involved in interleukin- 6 and interleukin-8 expression in fibroblast-like synoviocytes stimulated by protein I/II, a modulin from oral streptococci. Cell Microbio/ 2001 , 3:703-712.

22. Mosmann T: Rapid colorimetric assay for cellular growth and survival: application to proliferation and cytotoxicity assays. J Immunol Methods 1983, 65:55-63.

23. Semaan N, Alsaleh G, Gottenberg JE, Wachsmann D, Sibilia J: Etk/BMX, a Btk family tyrosine kinase and Mal contribute to the cross talk between MyD88 and FAK pathways. J Immuno/ 2008, 180:3485-3491.

24. Robinson CM, Hale PT, Carlin JM: NFKB activation contributes to indoleamine dioxygenase transcriptional synergy induced by IFN- $\gamma$ and tumor necrosis factor-a. Cytokine 2006, 35:53-61.

25. Ohmori Y, Schreiber RD, Hamilton TA: Synergy between interferon- $\gamma$ and tumor necrosis factor-a in transcriptional activation is mediated by cooperation between signal transducer and activator of transcription 1 and nuclear factor KB. J Biol Chem 1997, 272:14899-14907.

26. Mun SH, Kim JW, Nah SS, Ko NY, Lee JH, Kim JD, Kim do K, Kim HS, Choi JD, Kim SH, Lee CK, Park SH, Kim BK, Kim HS, Kim YM, Choi WS: Tumor necrosis factor alpha-induced interleukin-32 is positively regulated via the Syk/protein kinase Cdelta/JNK pathway in rheumatoid synovial fibroblasts. Arthritis Rheum 2009, 60:678-685.

27. Shoda H, Fujio K, Yamaguchi Y, Okamoto A, Sawada T, Kochi Y, Yamamoto K: Interactions between IL-32 and tumor necrosis factor-a contribute to the exacerbation of immune-inflammatory diseases. Arthritis Res Ther 2006, 8:R166.

28. Goronzy JJ, Weyand CM: Rheumatoid arthritis. Immunol Rev 2005, 204:55-73.

29. Kasperkovitz PV, Verbeet NL, Smeets TJ, van Rietschoten JG, Kraan MC, van der Pouw Kraan TC, Tak PP, Verweij CL: Activation of the STAT1 pathway in rheumatoid arthritis. Ann Rheum Dis 2004, 63:233-293.

30. Schulze-Koops H, Kalden JR: The balance of Th1/Th2 cytokines in rheumatoid arthritis. Best Pract Res Clin Rheumatol 2001, 15:677-691.

31. Choi JD, Bae SY, Hong JW, Azam T, Dinarello CA, Her E, Choi WS, Kim BK, Lee CK, Yoon DY, Kim SJ, Kim SH: Identification of the most active interleukin-32 isoform. Immunology 2009, 126:535-542.

32. Gorelik L, Gilbride K, Dobles M, Kalled SL, Zandman D, Scott ML: Normal B cell homeostasis requires $\mathrm{B}$ cell activation factor production by radiation-resistant cells. J Exp Med 2003, 198:937-945. 
33. Elias J, Krol ACR, Freundlich B, Sampson M: Regulation of human lung fibroblast glycosaminoglycan production by recombinant interferons, tumor necrosis factor, and lymphotoxin. J Clin Invest 1988, 81:325-333.

34. Jiang D, Liang J, Noble PW: Hyaluronan in tissue injury and repair. Annu Rev Cell Dev Biol 2007, 23:435-461.

35. Midwood K, Sacre S, Piccinini AM, Inglis J, Trebaul A, Chan E, Drexler S, Sofat N, Kashiwagi M, Orend G, Brennan F, Foxwell B: Tenascin-C is an endogenous activator of Toll-like receptor 4 that is essential for maintaining inflammation in arthritic joint disease. Nat Med 2009, 15:774-780.

36. Brentano F, Schorr O, Gay RE, Gay S, Kyburz D: RNA released from necrotic synovial fluid cells activates rheumatoid arthritis synovial fibroblasts via Toll-like-receptor 3. Arthritis Rheum 2005, 52:2656-2665.

\section{doi: 10.1186/ar3073}

Cite this article as: Alsaleh et al., Innate immunity triggers IL-32 expression by fibroblast-like synoviocytes in rheumatoid arthritis Arthritis Research \&

Therapy 2010, 12:R135

Submit your next manuscript to BioMed Central and take full advantage of:

- Convenient online submission

- Thorough peer review

- No space constraints or color figure charges

- Immediate publication on acceptance

- Inclusion in PubMed, CAS, Scopus and Google Scholar

- Research which is freely available for redistribution

Submit your manuscript at www.biomedcentral.com/submit
C) Biomed Central 